\title{
Media education in the common interest: Public perceptions of media literacy policy in Latvia*
}

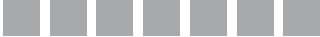 \\ Anda Rožukalne \\ ORCID: 0000-0001-5474-4222
}

RIGA STRADINS UNIVERSITY, LATVIA

Ilva Skulte

ORCID: 0000-0002-4589-6600

RIGA STRADINS UNIVERSITY, LATVIA

Alnis Stakle

ORCID: 0000-0002-0962-0076

RIGA STRADINS UNIVERSITY, LATVIA

https://doi.org/10.19195/1899-5101.13.2(26).4

\begin{abstract}
Although the academic interest in media and information literacy (MIL) is ever increasing, there are not many studies that analyze the public perception of media literacy. This article analyses the interrelations between encouragement measures implemented by media policy and the perception of media literacy in society. The research employs data from a national representative survey (May 2019; $\mathrm{N}=1,017$ respondents). The study explores the respondents' media literacy perceptions; opinions on risks potentially caused by insufficient media literacy skills; and respondents' experience with MIL activities. The survey results are compared with survey data on media literacy encouragement measures, aims and target audiences obtained from the Media Policy Unit at the Ministry of Culture media literacy partners. The theoretical background is supported by the media literacy ideological model, which explains media literacy within relationships with the social institutions in which it is practiced, as well as social processes. The data results are controversial. Even though more than half of Latvia's population view their media literacy knowledge as insufficient, $52 \%$ of the respondents are not interested in MIL issues. Concerning the consequences of insufficient media literacy skills within society, the respondents focused mostly on threats to children $(40 \%)$ and general public safety $(28 \%)$, decrease in welfare $(28 \%)$, societal regress (25\%), fewer opportunities for high-quality education (26\%) and Latvia being behind other EU countries (24\%). Even though the media literacy encouragement measures in Latvia include activities aimed at various audiences, they have been noticed by only a slight number of respondents (7-10\%).
\end{abstract}

KEYWORDS: media literacy, perceptions of media literacy, media politics, Latvia

* This work received support from the European Union ERASMUS+ Strategic Partnership project "Media and Information Literacy \& Innovative Teaching Methods Laboratory" No. 2017-1-LV01KA203-035429. 


\section{INTRODUCTION}

After the collapse of the USSR, the media system in Latvia, as well as in other Baltic and CEE countries, developed towards the liberal model with clear differences in journalistic culture and relationships with politics in the Latvian and Russian speaking media of Latvia. Even if globalisation and technological innovations introduced hybridity into media norms and practices, state intervention into the media market was minimal. This led to the growth of both international and domestic corporations - close to economic and political elites of the country - bringing down the indicators of trust in the media that are significantly lower in Latvia than in both of the other Baltic countries (Standard Eurobarometer, 2018).

MIL in Latvia had no formal distinction up until 2016, when the first-ever guidelines for media politics in Latvia were accepted (Cabinet of Ministers, 2016). MIL activity was largely dependent on the interest of school teachers in MIL knowledge and skillsets; and libraries contributed to activities dedicated to improvement of the society's information literacy and digital skills (Centre of Culture Information Systems, n.d.). The first decade of the $21^{\text {st }}$ century in Latvia's media politics viewed media literacy and digital skills as interchangeable notions (İvāne, 2015), while media education, for example, still is not properly included into the definition of MIL used by policymakers. An analysis of MIL activities outside the formal education system found that MIL projects in Latvia have mostly been implemented by professional associations of technology and internet companies (Freibergs, 2015); therefore, these projects cover a small fraction of MIL tasks and audiences. FrauMeigs and colleagues (2017) proposed a theoretical framework for the analysis of functionality of MIL governance that included four elements - a coherent policy system with a clear vision of MIL; co-ordination between public sector institutions; development of capacity building and professionalism; and governance processes with the involvement of other actors and multi-stakeholders. According to this model, it can be said that the processes of MIL governance in Latvia have begun in all four aspects. However, developments in capacity building and professionalization and the building of a network to involve other actors has achieved much more visibility (still waiting for deepening and strengthening), with a clear vision of policy and interinstitutional coordination still lagging behind.

Recent comparative research on media and information literacy (MIL) policies in Europe shows that Latvia has an historically underdeveloped and rather weak framework of MIL policies (Frau-Meigs et al., 2017, p. 27). EU Media Pluralism Monitor data from 2015 to 2017 (MPM, 2018) on media literacy development in Latvia evaluated MIL policy as underdeveloped. The National Development Plan of Latvia for 2014-2020 does not include media literacy (Cross-Sectoral Coordination Centre, 2012). The next version of the Plan for 2021-2027 (Cross-Sectoral 
Coordination Centre, 2019) connects media literacy to the importance of the skillset to distinguish 'fake news' and check information sources on social media.

One of the five core principles in Latvia's media politics is dedicated to media literacy (Cabinet of Ministers, 2016). It is expected that the fulfilment of the media politics plan should ensure a growth in media literacy by $15 \%$ in children and adolescents and by $7 \%$ in adults by 2020 . Since the development of the plan, a base for media literacy in mandatory education has been created (Skola 2030), as well as training for education specialists and gradual changes in pedagogy study programs (University of Latvia, 2019).

In this article, interrelations are analyzed between encouragement measures implemented by media policy and perceptions of media literacy in Latvian society. The study explores the respondents' media literacy perceptions; opinions on risks potentially caused by insufficient media literacy skills; and respondents' experience with MIL activities. The research objective is to analyze interrelations between encouragement measures implemented by media policy and the perception of media literacy in society.

\section{DEFINING MIL IN EUROPEAN UNION AND LATVIAN POLICIES}

One of the main aspects in developing MIL policies is a clear vision that is supported by a comprehensive and applicable definition of MIL and is embedded in the value system (Trültzsch-Wijnen et al., 2017). European policy is based on an understanding of MIL as a changing list of competences that are structured around three main components (UNESCO, 2013, p. 56) - access, evaluation and creation. The European Parliament and the Council of the European Union (2018) directly connect MIL to 'skills, knowledge and understanding that allow citizens to use media effectively and safely' [...]; and the acquiring of MIL doesn't mean only instrumental skills, 'but should aim to equip citizens with the critical thinking skills required to exercise judgment, analyze complex realities and recognize the difference between opinion and fact'.

In Latvian media policy, basic documents define media literacy as the knowledge and skills needed to work with information sources - to find and analyze information, understand functions of the providers of information, critical evaluation of information, deferring between critical and biased information, comparing the news from different sources in order to make one's own opinion. Media literacy includes also the skills of practical use of media' (Cabinet of Ministers, 2016; translated by the authors). This definition is harmonized with European MIL policy documents and based on the critical perspective on MIL. However, this definition does not necessarily include aspects of media specifics (multimodal communication), creativity in media, access, active citizenship and understanding of the role of media in a democracy (for a wider discussion of the concept of media literacy, see Cappello, 2017).

It must also be noted that, until now, mostly ICT competences in the form of practical skills have been included in the practical implementation in education at schools 
as well as in after-school teaching. It shows that there is little observable consequence in the policing of MIL. The reasons for that can be found in political culture and the history of the country - the lack of a longer tradition of democracy and citizen participation, power distance of economic and political elites, common-sense understanding of the role of mass media and press freedom and the base of sociocultural values and traditions as they appear in the relationship between media and politics. In other words, critical literacy is a difficult concept to introduce in a society where '[p]olicy documents attribute a lack of sociality to flawed personal identity which is to be corrected by inculcation of higher-order preferences in government-managed cultural socialization' (Kruks, 2018, p. 41). This is why we adopt two main models for analysis of data in this article - the ideological model of MIL combined with a critical literacies paradigm; and a media systems theoretical tradition to understand the norms and values surrounding media and politics and explain choices made by policymakers and the reception of them in wider audiences.

\section{MIL in Latvia's media politics}

Media politics represents the leading media-related political ideas in a given country. Analysis of Latvia's media politic documents shows that the second decade of the 21 st century expects media politics to provide a variety of high-quality professional journalism, accountability and professional development (LR Ministry of Culture, n.d.). In the context of media politics, media literacy is understood as the society's skill in the use of current communication technology, as well as the ability to react to threats towards an individual or the society caused by changes in the information environment.

MIL in Latvia had no formal distinction up until 2016 when the first-ever media politics guidelines in Latvia were implemented (Cabinet of Ministers, 2016). MIL activity was largely dependent on teacher interest in MIL knowledge and skillsets, and libraries contributed to activities dedicated to improvement of the society's information literacy and digital skills (Centre of Culture Information Systems, n.d.). A 2015 analysis of MIL activities outside the formal education system found that, since 2010, media literacy projects in Latvia have mostly been implemented by professional associations of technology and by Internet companies; therefore, these projects cover a small fraction of MIL tasks and audiences (Freibergs, 2015). A report on MIL by the Audiovisual Media Observatory underlines that public-private partnerships in the development of MIL are to be welcomed; however, the structure of this cooperation in Latvia shows that policymakers do not have clear MIL development priorities.

Data from the EU Media Pluralism Monitor (from 2015 to 2017; MPM, 2015, $2016,2018)$ on media literacy development in Latvia has evaluated MIL policy as underdeveloped (e.g., it creates medium risk for media pluralism). This conclusion is based on indicators which show that MIL policies are not well implemented in Latvia, and media literacy in the country is limited. It means that there are 
occasional trainings for teachers, and the subject of media literacy is present to a limited extent in both formal and informal education.

Until 2016, the main institutions to introduce the notion of media literacy in public discourse were the National Electronic Mass Media Council (NEMMC; NEPLP, n.d.) and the Ministry of Education and Science. The National Development Plan of Latvia for 2014-2020 does not include media literacy (Cross-Sectoral Coordination Centre, 2012). The National Development Plan of Latvia for 2021-2027 connects media literacy to the necessity of decreasing the segregation in society caused by foreign political rhetoric. It also emphasizes the importance of the skillset to distinguish fake news and check information sources on social media (Cross-Sectoral Coordination Centre, 2019).

The first decade of the $21^{\text {st }}$ century in Latvia's media politics viewed media literacy and digital skills as interchangeable notions. This is clearly seen in the implementation of the 2015 pilot project 'Digital competence in education process' (Ivāne, 2015), which outlined information technology education in the curriculum of primary and secondary schools as well as improvement of the digital skills of education specialists. The presentation of the pilot project quotes the 2009 recommendations of the European Commission, which focused on critical evaluation of media content, tolerance and acceptance of different opinions. However, the Latvian project concentrates mostly on information literacy and digital skills (İvāne, 2015).

Latvia's media politics views media literacy as a tool to help an individual to adapt to changes in the public communication environment and as a contributor in diminishing disputes between social groups. The MIL skill to 'critically evaluate media stories' has been interpreted as a contribution to encourage 'communicative integration in society'. Latvia's media politics (Cabinet of Ministers, 2016) demonstrates the view that media literacy strengthens an individual's creativity, allows recognition and prevention of biased information, and distinguishes the media that supports highquality, reliable journalism. Media literacy on a national level has been emphasized via another principle, the 'media environment securitability', as 'the media field in Latvia is strategically important to maintain and preserve the national security and cultural environment' (Cabinet of Ministers, 2016). The document expects that the fulfilment of the media politics plan should ensure a growth in media literacy by $15 \%$ in children and adolescents and by $7 \%$ in adults by 2020 . Latvia's media politics prioritizes strengthening of the traditional media environment and aims to improve it by increasing variety and content quality. The changes in public communication caused by Web 2.0 technologies, media globalization and social media influence are only considered in the media politics section regarding media literacy.

\section{The context of media literacy and politics in Latvia}

Compared to other Baltic states (Standard Eurobarometer, 2018), Latvia shows a low level of trust in media (18\% of the population as compared to $28 \%$ in Lithuania and 
$29 \%$ in Estonia). Russian media are trusted by $65 \%$ of the respondents who use the Russian language in their daily lives and $21 \%$ of those who use Latvian (Laizāne et al., 2015).

The priorities of MIL politics in Latvia have been greatly affected by data on the society's media use, which emphasises the linguistically divided (MPM, 2016) media environment caused by the differences in media repertoire between the speakers of Latvian and Russian.

Thirty-two percent of the Russian-speaking population of Latvia (Latvia's Facts, 2017), acquire their daily information in Russian. Research on social thought reveals the contrasting views of the Latvian population when it comes to evaluation of events in Latvia and the neighboring countries. In 2014, when questioned about Russian politics in the Ukraine, $45 \%$ of Latvia's minority representatives did not support Russian military forces in the Ukraine, whereas 29\% supported it (SKDS, 2014). In 2017, (LR Parliament, 2018), 45\% of Latvia's Russian-speaking population agreed that Latvia could not exist as an independent country.

Another important aspect in understanding media literacy in a political context is the geopolitical situation: Euromaidan events (2013) in Kyiv and the Russian annexation of Crimea in 2014. These events facilitated the notion of 'information/ hybrid war' in the public discourse, as well as extensive Russian propaganda in the digital environment - the so-called 'Kremlin Internet troll factory' (Rožukalne \& Sedlenieks, 2017) activity in EU information channels. The geopolitical events from 2014 onwards raised the issue of Latvia's media and society resistance against the Russian propaganda (Andžāns et al., 2016), as well as the impact of Russian propaganda on state security (LR Parliament, 2018). Upon development of the media politics that were officially accepted in 2016, experts of the Culture Ministry Department of Media Politics attempted to react to the new challenges in the public communication environment: the increasing social media influence, widespread disinformation and third country intervention in electoral politics.

\section{MEDIA LITERACY RESEARCH IN LATVIA}

Development of media politics has caused an increased number of projects that research the media literacy of the society. Researchers have conducted surveys to determine the self-evaluation of media literacy in Latvian society, as well as the evaluation of disinformation and its impact. Children and adolescents have been emphasized as an important group of the target audience, and researchers have analyzed social media use among youth: their ability to protect themselves against digital environment risks and distinguish reliable information.

In a 2017 survey on media literacy in Latvia, $40 \%$ of the respondents claimed (Latvia's Facts, 2017) that they can distinguish reliable, biased and false information. A higher self-evaluation of this aspect was presented by the age group 25-34, as well as respondents with higher education and higher income. Twenty-two percent of 
the respondents admitted to having believed biased or false information and to realizing the mistake later; $11 \%$ were critical in their evaluation of the ability to notice fake news; and $27 \%$ said they cannot evaluate their skill to distinguish reliable information from manipulative content. Thirty-five percent of the respondents showed interest in media literacy, most frequently those in the $24-44$ age group. Most (85\%) respondents would like the media to provide information on media literacy.

The importance of media literacy was revealed in a research on children and adolescent media literacy (University of Latvia, 2017). Ninety-two percent of the participants aged 9 to 16 owned a smartphone. Most (66\%-88\%, depending on the age group) used the Internet on their smartphones for at least 3 hours every day. The most frequent activities were watching videos (70\%), messaging (68\%) and social networking (66\%). Each participant group displayed a different self-evaluation on Internet skills. Seventy-four percent of the representatives of the older group (ages 13-16) and $43 \%$ of the younger group (ages 9-12) were confident in their skill to adjust privacy settings and block unwanted communication. Twenty-eight percent of the younger group admitted they lacked the skill to adjust privacy settings on social networks.

A 2017 SKDS research offered data on the attitude of Latvia's population towards untrue news (Kaktiňš, 2017). Each fourth to fifth inhabitant of Latvia thought that mass media, social media and the Internet frequently offer fake information. Fiftythree percent of the respondents were convinced that deceptive news influences the society greatly or rather greatly, $44 \%$ of the respondents claimed they had good skills to recognize fake information, but $35 \%$ assessed their skills as weak or very weak. However, the experiment included in this research showed that even the respondents evaluating their skills as strong or very strong could not recognize fake information.

An analysis of Latvia's youngest media audience revealed that the interviewed youngsters understood fake news, and some could explain why fake news was being spread. However, most claimed that the school did not discuss relevant issues, and their comprehension of fake news was acquired mostly through their own experience (Spurava, 2017, pp. 25-26).

The conclusions of these studies show that the data available on media literacy in Latvia is still insufficient - it includes only some of the aspects (more concentration on fake news, fact checking and young audiences; and one's own self-evaluation of media literacy is mostly involved without in-depth reflection of the sense and purpose of media literacy in the social and political context.

\section{Critical understanding of MIL and the ideological model of literacy}

Social and political context is important in the ideological model of literacy. This model is useful to interpret the relationship between the state and individuals and their supposed responsibilities and expectations in regard to media and information literacy. It allows the development of a critical interpretation of the media 
policy-promoted concept of media literacy (see previous chapter) and an understanding of the impact it could have had on public perceptions of MIL.

The ideological model of literacy, as an alternative to the so-called 'autonomous' model of literacy, was proposed in the 1980s by Brian Street $(1984,1994,2006)$. It was first done in the context of searching for a new paradigm in literacy studies that would reject the idea of a literate person as an autonomous individual completely responsible for his or her acts of acquiring the skills and competences to be adequately educated to live in accordance with the cultural contex - values, norms and cultural practices - and be competitive in the situations of social life and work (Elmborg, 2012, p. 80; Loveless \& Longman, 1997). Another intention in developing the model was an ambition to change the concept of literacy by breaking with its fundamental placement within the cognitive psychological understanding of learning and move on to include more situational, critical and social practice aspects (Gee, 2007, 2015).

According to the model, literacy, for example, MIL, should be examined in social contexts and is determined by the social relations, cultural traditions and ideological conditions established in the given society. This means that one concept of literacy cannot be taken over and automatically applied to analyze any time and any society, as there is no one abstract and general context of literacy for all societies, cultures, social groups and ethnic groups. In other words, along with other common sense concepts that are taken for granted in a society hic and nunc, literacy was understood as an ideological construct implementing the perspective of a particular dominant class or social group through the conventions and practices strengthening given social formation 'as if it were natural, universal, or, at the least, the end point of a normal developmental progression (achieved only by some cultures, thanks either to their intelligence or their technology)' (Gee, 2015). The model underlines the importance of understanding the learner experience (Street 1984, $2003,2006,2011$ ) and social context - policymaking, educational system, school, workplace, family life and leisure - and provides a culture-specific view of media and information literacy where it arises and develops (Loveless \& Longman, 1998). It allows consideration of the need to exercise one's citizenship in democracy, or more for individual self-actualization and cultural expression only, especially when put in the perspective of possible 'individual governance' by using media technologies (Livingstone, 2004, p. 11). It puts under critical (e.g., socially, economically, politically) questioning the science-based approach to MIL (Leaning, 2017, p. 35) as well as enthusiasm around the introduction of media technologies in education (Buckingham, 2015; Cappello, 2017) and other areas of public governance. The critical approach is the backbone of understanding MIL. Critical media literacy stands for inclusion in the analysis of messages on issues of 'socio-political contexts, control, capitalism, resistance and pleasure' (Kellner \& Share, 2019). It supports 'enhanced awareness of self and community' (Song, 2017) and creative and purposeful use of media by an individual (Stakle, 2011, p. 51). 
In this study, we include critical media literacy as a core element in the definition of MIL but base our approach upon the ideological model of literacy that allows an understanding of how policy measures interpret MIL in the given social and political situation by actually narrowing the concept of MIL and taking it out of its democratic contexts. MIL is understood in this article as an ability to access, search, work with and critically evaluate information in a diversity of channels by understanding how and with what intent messages are produced in order to act (using media) as a responsible citizen exercising democratic rights. (Cappello, 2017). This approach stresses the need for a proper and more reflexive understanding of the purposes of MIL in the broader context of democratic society.

\section{MIL in the context of a media system: Latvian features}

Four criteria have traditionally been employed to characterize media systems (Hallin \& Mancini, 2004): the role of the state, the influence of politics, the level of regulation and the professional quality of journalism. The liberal structure of Latvian media regulation has allowed a diverse media system to develop; at the same time, the media environment is characterized by oligopolistic competition and a high level of concentration (Jastramskis et al., 2017). Using Hallin and Manchini's (2004) media system models, the Latvian media system is described as hybrid because it lacks a dominant paradigm (Skudra et al., 2014). First, the important role of the market in the regulation of the media landscape, and the lack of support for professionally competitive media, are indicative of a liberal model. Second, democratic corporate features of the model are evidenced by the efforts to strengthen public service media and a few media professionalization activities in the country. Third, the presence of political parallelism in the media environment and the great influence of political public relations on media content mark the signs of a polarized pluralistic model.

The three models of media systems developed by Hallin and Mancini have always been difficult to adapt for an analysis of the media environment of Central and Eastern European (CEE) countries. Analyzing political systems, economic development and consequences of media privatization in 21 CEE states, Dobek-Ostrowska (2015) developed four models of media and politics in CEE. The author placed Latvia in the Hybrid Liberal Model. This means that the Czech Republic, Poland, Slovakia, Estonia, Latvia and Lithuania are richer than the other CEE states; all these states have acquired a 'free' country status. At the same time, they belong to the group of flawed democracies. Although the countries in this group have higher democratic standards and lower levels of media politicization, the Baltic States are deemed to have a decline in public trust in politics and media (Dobek-Ostrowska, 2015).

In addition, three rival journalism cultures can be distinguished in Latvia by their attitude towards accountability (Dimants, 2018). The ethnic minority media are represented by the traditional Russian journalism culture. The instrumental 
and authoritarian (post-Soviet) journalistic culture characterizes the media that are not independent from political and economic subsystems of the society. Finally, the professional media culture, oriented towards high professional standards and editorial autonomy, can also be identified.

An important aspect to understand the media system in Latvia and the complexity of MIL policy is its linguistically divided (MPM, 2018) media environment. Latvia is not ethnically homogenous: $62 \%$ of the population is Latvian, $25 \%$ Russian, 3.2\% Belarussian, 2.2\% Ukrainian, 2.1\% Polish and 4\% other. Sixty-one percent of the Latvian population speaks Latvian as the first language, $36 \%$ speak Russian and 3\% speak other languages (Central Statistical Bureau, 2018). Research data shows that the Russian media are trusted by $65 \%$ of the respondents who use the Russian language in their daily lives and $21 \%$ of those who use Latvian (Laizāne, et al., 2015). The geopolitical events from 2014 onwards raise the issue of Latvia's media and society resistance against Russian propaganda (Andžāns et al., 2016), as well as the impact of Russian propaganda on audiences and state security (LR Parliament, 2018).

\section{METHODOLOGY}

The purpose of this study is to analyze interrelations between encouragement measures, implemented by media policy, and media literacy perceptions in society. We based our research on the following assumptions: First, beliefs, values and traditions must be considered for a proper introduction and analysis of MIL, as they form the base for a country's media system. Thus, the Latvian media system specifies the way in which MIL policy measurements are noticed, accepted and supported in Latvian society, especially when connected to the direct threats and risks that the lack of MIL can create for the welfare and safety of society and individuals - the risks and threats that MIL policy is aimed to avoid or diminish.

Second, the understanding of the concept and criteria of literacy is considered to be dependent on the social and/or cultural context and the ideology of the respective social groups in the critical approaches of MIL theory. This is the reason we tried in our approach to analyze the main failures of the MIL policies in Latvia in connection to the dominant ideology. We also compared different social groups in terms of how they are reached by MIL actions and how they form their attitudes towards MIL.

The main research questions of this study are as follows: 1) What characterizes the society's perception of MIL in Latvia? 2) How do the level and quality of information about MIL among the general population in Latvia correlate with the importance given to MIL in the framework of competences needed to participate in social life, ensuring social welfare and safety? 3) To what extent have the media policy measures for promoting MIL reached the Latvian population?

As for the research method, face-to-face interviews were conducted at the respondents' residences in the time from 11 May 2019 to 22 May 2019. As a sampling 
method, multistage stratified random sampling was used. 'Area frames play a central role in multi-stage sampling. At every stage of selection, a different area frame is used. Selecting a multi-stage sample from area frames is the most common way to obtain a geographically clustered sample. The population has been divided into homogeneous groups called strata to select a sample independently from each stratum' (T. Kennel, 2008). The sample is representative of the general population of Latvia. Stratification criteria were administrative-territorial divisions of Latvia. A definite number of districts was selected from the list of all (26) of the administrative districts of Latvia using probability sampling. This sample of districts was proportional to the regional division of permanent residents in Latvia: Riga 34.1\%, Vidzeme 23.0\%, Kurzeme 13.3\%, Zemgale $14.1 \%$ and Latgale $15.5 \%$. Using probability sampling, 127 places of residence were selected from the districts according to the number of residents and the urbanization level. The sample included 1,017 permanent residents of Latvia between the ages of 18 and 75 . Using the research design created by the authors of this article, the fieldwork was conducted by research company SKDS. The answers to the questions were graded and coded for the data to be statistically analyzed using the SPSS software.

To compare results of a general survey with the practical implementation of MIL policies, a survey was used to find out what kind of social partners (NGO's, schools, libraries, etc.) are included in the network organized by the Ministry of Culture. In this part of the research, we distributed a questionnaire to 50 network collaborators containing 9 questions regarding their types of activities, target audiences and methods used. In total, 29 answers were collected and processed manually.

\section{RESULTS}

The answers to the first question in the survey on interest about media and information literacy divided the population of Latvia into two main groups (Figure 1). The larger group, i.e., more than half of the respondents, were not interested in MIL, while more than $40 \%$ of the respondents were interested in the topic.

A detailed analysis of the data showed that females were generally more interested in media literacy-related issues than males. A greater interest was displayed amongst groups of respondents aged 18-54 than those aged 55-75. Education proved to be an influential factor: the higher the education, the greater the interest. Almost two-thirds of the respondents who had tertiary education were interested in media literacy, as compared to less than half of those with secondary or vocational education and one-quarter of those with primary education. Almost half of Latvian respondents and more than one-third of respondents with other nationalities were interested in MIL. The results were not influenced by the language used daily by the respondents' families. Citizens of Latvia were more interested in MIL than non-citizens. A higher interest in MIL was found among those with high/above average income levels and those living in the capital city Riga and its vicinity and the Vidzeme district. 


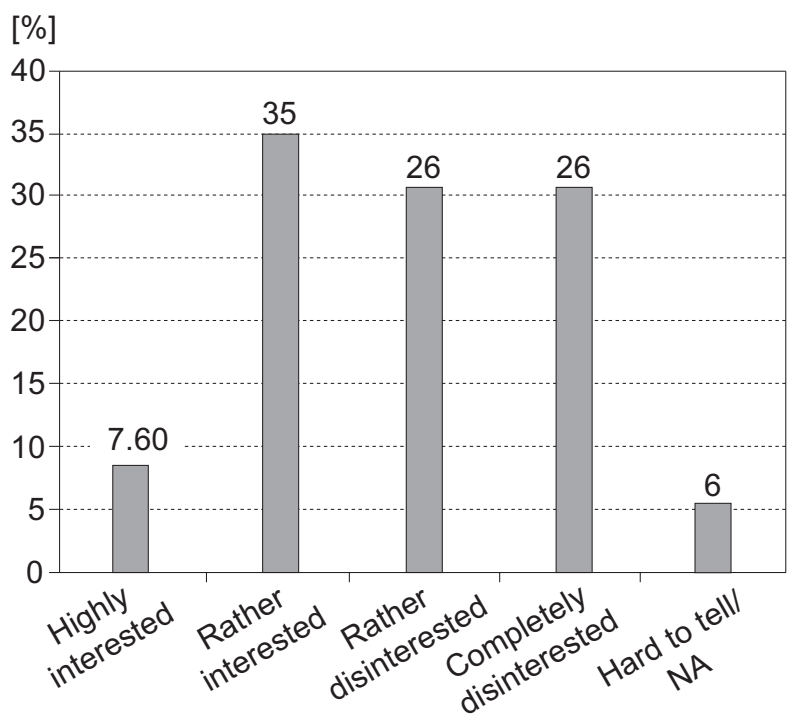

Figure 1. To what extent are you highly interested and rather disinterested in the issues of media literacy? (\%) $\mathrm{N}=1017$.

When asked to evaluate their own media literacy skills, one-third (34\%) of the respondents claimed to possess sufficient skills. Only $5 \%$ evaluated their skills as very good and $29 \%$ as rather good. More than half (57\%) of the respondents admitted to having weak skills (33\% rather weak, $23 \%$ very weak); one-tenth choose not to answer.

\section{Description of the selected respondent groups}

Based on research data and responses related to skills, knowledge and interest in MIL, four groups of respondents were identified. We called them as follows:

Group 1: the knowledgeable and interested (26\%)

Group 2: the interested but lacking knowledge (15\%)

Group 3: the uninterested but knowledgeable (7\%)

Group 4: the uninterested and unknowledgeable (39\%)

The largest group was Group 4, namely, those with neither interest nor sufficient knowledge in MIL. This group consisted of more men (43\%) than women (36\%), and a considerable fraction (63\%) fell between the ages of 45-75. This group more than the others included respondents with primary education and secondary or vocational education (87\%). The group consisted of similar proportions of Latvians (37\%) and other nationalities (42\%). The respondents belonging to Group 4 mostly received low (53\%) or below average (41\%) income. A larger number of respondents lived outside the capital city in smaller towns or rural areas. 
The second largest group of respondents - Group 1, the interested and knowledgeable, amounting for $26 \%$ - had a similar proportion of males and females, most falling between the ages of 18-44 (65\%). The group showed relatively high numbers of professional leaders or chairpersons (55\%); field experts, state employees (40\%); people with income levels above the average (32\%) or high $(34 \%)$, as well as inhabitants of the capital city Riga and its economically flourishing vicinity.

The remaining two groups, Group 2 and 3, had a lower number of participants than the other two groups. Groups 2 and 3 did not display any significant sociodemographic differences. Group 2 consisted mostly of females, people aged 45-75, farmers and individual workers and people with average income. Group 3, the respondents with no interest but sufficient knowledge of MIL, were most frequently youth, manual workers and housewives.

Next, with each group, we inquired into potential threats caused by insufficient MIL knowledge and skills, about the necessary amount of MIL knowledge, and measures that should be taken to minimise the risks to society.

\section{Characteristics of threats to society caused by insufficient MIL knowledge}

In answer to the question about the greatest threats to Latvia and its society that could be caused by insufficient knowledge of media literacy, more than one-third of the respondents believed insufficient knowledge of MIL would cause a threat to the safety of children (Figure 2). There were different types of eventual threats emphasised by one-third of the respondents. Participants in the survey believed that lack of MIL knowledge can cause lower levels of wellbeing and prosperity in a country; weak MIL knowledge can be related to threats to the safety of the society in general and to degradation of society. One-quarter of respondents pointed out that insufficient MIL knowledge may cause fewer opportunities for high-quality education and hindrance in Latvia's progress as compared to other EU countries. Nearly every fifth respondent emphasised that lack of MIL knowledge could lower healthcare quality and cultural development. Every sixth participant mentioned at least one insufficient MIL knowledge threat as follows: higher rates of violence, threat to Latvia's independence and state security, problems of domestic politics (such as election trends and results) and degradation of mass media or disappearance of high-quality media due to lack of demand. A small minority of respondents believed that poor knowledge of MIL leads to a worsening of national culture.

Applying sociodemographic criteria to the threat response analysis, it can be observed that the potential threat to child security is of concern to more women (46\%) than men (35\%) and to respondents with tertiary education (45\%). This threat was recognised more by citizens of Latvia (42\%) than by non-citizens (27\%); it was identified more often by public sector employees (48\%) and people with income levels above average (46\%) or high (44\%). Evaluation of the threat of a decreased wellbeing and prosperity is not differentiated by sex, age or education; respondents 
aged 55-63 (22\%) and those with primary education (18\%) marked the answer less frequently than others. The threat to the safety of the general society was evaluated similarly across different socio-demographic groups.



Figure 2. What are the five greatest threats to Latvia and its society that could be caused by insufficient knowledge of media literacy? (\%) $\mathrm{N}=1017$.

All the groups identified the threat to the safety of children as the greatest concern. The two groups with weak MIL knowledge (Groups 2 and 4) marked the threat to the safety of the general society as the second greatest. Respondents interested in MIL were concerned about potential decreases in wellbeing and prosperity, whereas the uninterested pointed out the degradation of society.

Both respondent groups with insufficient MIL knowledge selected the same threat, that of a decrease in wellbeing and prosperity, as the third greatest concern. The uninterested and unknowledgeable respondents were more likely (26\%) to think that there is no threat to society associated with low MIL skills.

The groups with high MIL knowledge again differed in their views: the interested believed that weak MIL knowledge would lead to a possible decrease in education quality, whereas the uninterested pointed out a potential increase in 
violence. Regarding the fourth and fifth biggest threats, nearly all groups selected the threats already mentioned. Group 2 placed hindrance of Latvia's development in the fourth position as compared to the European Union; Group 3 identified as the fifth threat that insufficient MIL knowledge can cause a decrease in the level of culture in the society.

\section{Essential knowledge and skills of MIL}

When asked to select the most important knowledge and skills necessary to minimise individual and societal risks, more than half of the respondents (Figure 3) chose the ability to use a phone, smartphone, computer or the Internet. Almost half of survey participants thought it was necessary to know where to seek help in case of danger (internet threats, harassment). More than one-third of respondents emphasised the importance of various media and information literacy knowledge and skills as follows: awareness of how social media work, understanding of law (rights, copyrights, commercial practice, advertising, consumer rights); knowledge on how to restrict children's access to certain information; skills of selection and evaluation of information, the skill to check the legitimacy of facts and critical thinking. One in five respondents pointed out that proficient use of social networks and knowing how to control public information about oneself on different websites, databases and information processing systems is very important. Less than one-tenth of respondents identified the need for knowledge on mass media ethics and Internet business skills.

Comparing the data above to responses across groups, it can be observed that the respondents belonging to all groups chose the top three skillsets similarly. The representatives of all groups chose the ability to use digital devices, the knowledge of where to seek help in case of danger and the knowledge of social networking platforms as most important. Analysing the list of other MIL skills and knowledge, each group of respondents chose a different answer. Group 4 emphasised awareness and knowledge of law. Group 2 selected the skill to check the legitimacy of facts as more significant. Group 3 highlighted critical thinking as essential among the other knowledge and skills. Group 4 selected the skill to evaluate information. Groups 1 and 2 chose the skill to protect children on the Internet; that is, restrict information access.

In an inquiry into the steps and measures that should be taken to improve the society's media literacy, the respondents emphasised the role of the education system: $50 \%$ believed that secondary school curriculums should include mandatory education on media and its impact; $45 \%$ thought that this education should be included in high school curriculums; $32 \%$ expected more educational material about mass media; $28 \%$ thought that local and state governments should provide courses and trainings in media literacy; $25 \%$ claimed that tertiary education programmes should include MIL; $24 \%$ believed that there should be stricter rules for the media regarding make-up of risky information; and $17 \%$ wished to see more events and discussions on the topic. A minority of $5 \%$ thought that no measures should be taken and $8 \%$ were unsure. 


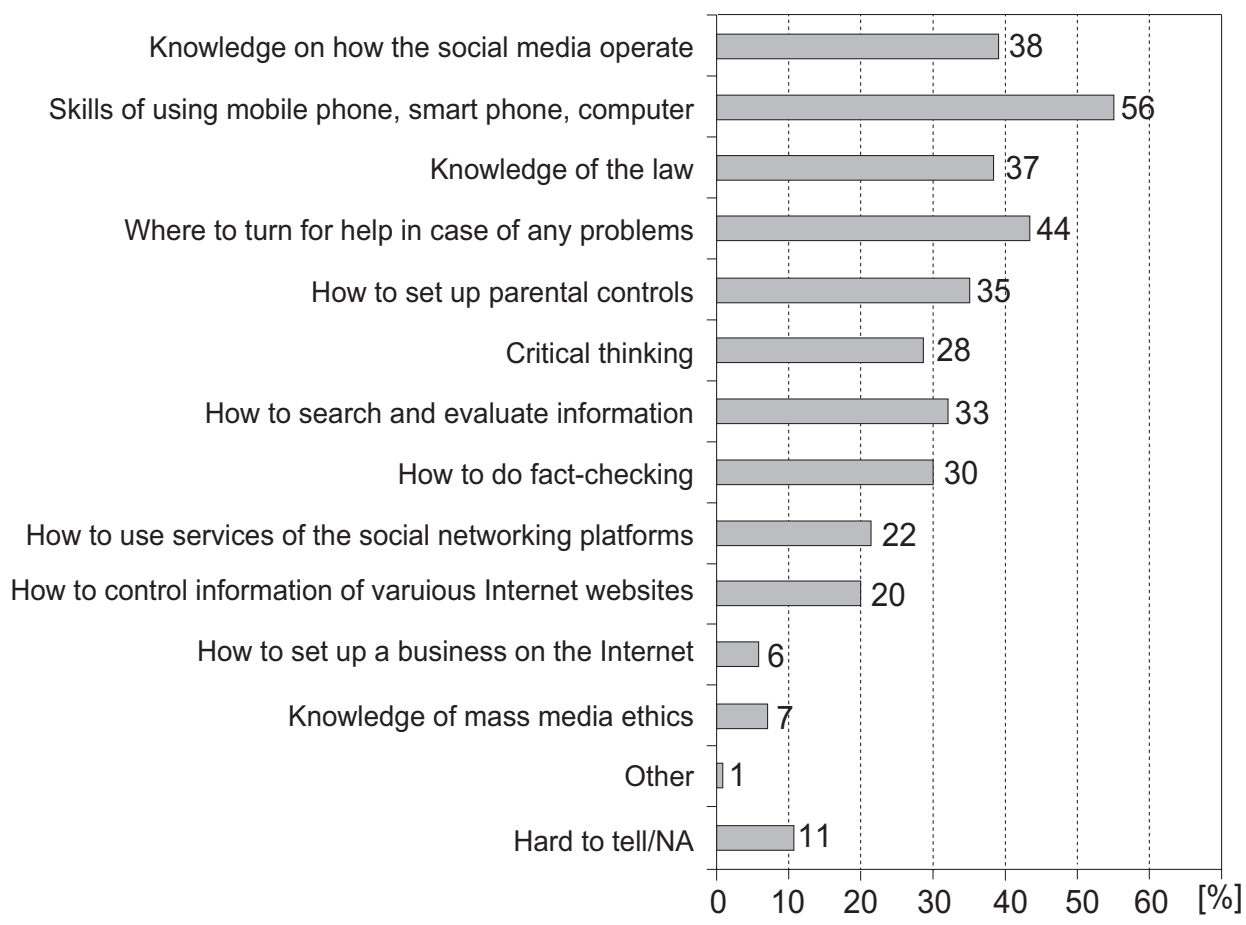

Figure 3. Which five knowledge aspects and skills do people need first and foremost in order to minimise the threats to themselves and the society? (\%) $\mathrm{N}=1017$.

Across groups, the respondents chose similar answers: first, that secondary school curriculums should include mandatory education on MIL; second, that this education should be included in high school curriculums; and third, more educational material in mass media should be provided.

Survey data showed that, in relation to minimising MIL risks to society, respondents supported regulatory and self-regulatory measures towards professional media and social networking platforms. More than one-third of participants believed that social media use should be controlled. About one-third of respondents supported strict monitoring of social media activities, the same number asked to ensure transparency of media activity (public information on website owners, codes of action, advertising algorithms) and identified that deceitful information must be fought. Thirty percent of respondents thought that MIL improvement measures should be taken. In order to reduce MIL-related risks, $20 \%$ of survey participants believed that highquality media must be supported; each tenth respondent thought that journalist selfregulation and international media platform self-regulation should be encouraged.

Evaluating the solutions in minimising MIL-related risks, representatives of Groups 1, 2 and 3 emphasised five main courses of action: first, to ensure the transparency of the Internet, and second, the need for extended control over social media use (supported by group 4 as well). Third, they endorsed stricter regulation of social 
media platforms and, further, to fight against distribution of fake news. Finally, respondents evaluated eventual measures to promote MIL in society. Groups 1 and 2, which were both interested in MIL issues, placed a greater importance on high-quality media support and encouraged self-regulation of international social networking media. All groups were equally supportive of promotion of journalist self-regulation.

Group 4, the uninterested and unknowledgeable, not quite unexpectedly, displayed the least support in relation to measures that should be taken to reduce risks. The representatives of this group selected only the necessity to control social media. The group also indicated that no action is needed to promote MIL (14\%), which is not supported by the other respondents, as shown in Figure 4.

Ensure transparency of Internet media activities

More control over social media use

Establish stricter regulation of social media

Increase support for quality media

Take measures to improve and promote media literacy

Increase support for quality media

Establish stricter regulation of social media

More control over social media use

Ensure transparency of Internet media activities

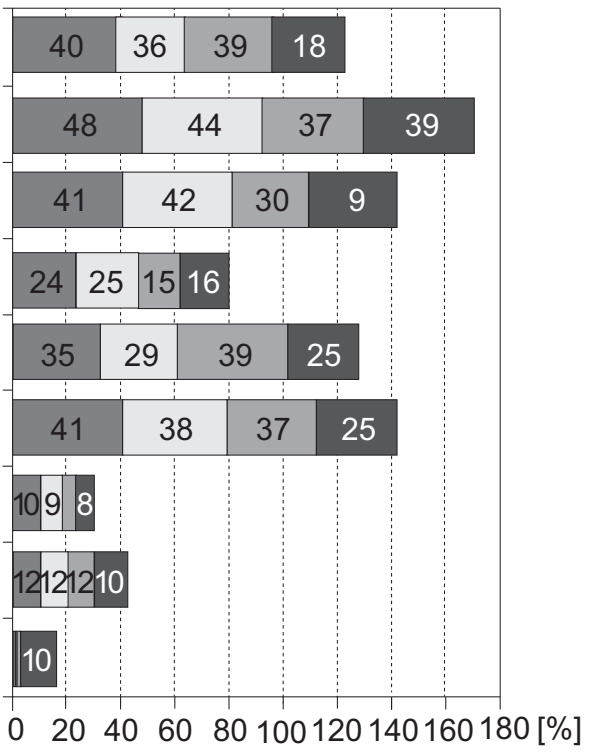

$$
\begin{aligned}
& \text { Interested in MIL, } \\
& \text { have good knowledge } \\
& \text { Not interested in MIL, } \\
& \text { have good knowledge }
\end{aligned}
$$

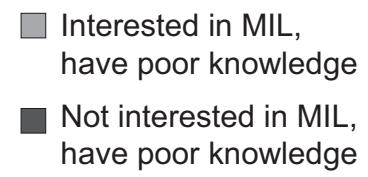

Figure 4. What should Latvia do to reduce MIL-related risks to citizens and society? (\%) N=1017.

\section{Evaluation of activities of media politics}

The last two questions out of the seven-question set included in the study were aimed at checking the extent to which the respondents had noticed the activities that Latvia's media politics had planned and carried out with different target audiences. Data showed responses to the question 'Which of the MIL-related issues mentioned below have you noticed in the past 12 months' were as follows: $41 \%$ of respondents admitted that they 
had not noticed any MIL activities. Correspondingly, 20\% had noticed an increased interest in mass media performance, better media-related skills and knowledge in society, as well as more information on media explaining disinformation characteristics. A total of $13 \%$ of the respondents had noticed that expert explanations helped navigate the use of technology and the internet. Only $10 \%$ had taken notice of MIL trainings for librarians and teachers and 8\% were aware of MIL-related events in libraries.

Responses to this question revealed significant differences among the identified groups. Group 1, interested and knowledgeable of MIL, noticed most activities, the most frequent being the increased interest in society about MIL-related issues, also pointed out by group 2; a rise in the skill level; and an increased proportion of MIL materials and high-quality content in the media. Groups 3 and 4, which were generally uninterested in MIL, noticed any activity less frequently than the general data shows (41\%); no activity was noticed by $53 \%$ of Group 3 representatives and $58 \%$ of Group 4, as shown in Figure 5.

The growth of quality media information that helps me navigate issues that are important to society

Broadcasts and articles that explain the various forms of misleading information

Expert's interpretative information helps guide you through the use of information and technology

The growing interest of people in how modern media works

Increasing media literacy and skills

Media literacy is becoming an important part of formal education

Participation of librarians and teachers in educational events on media literacy issues

Events in libraries on media literacy issues

I haven't noticed any of this

Difficult to answer/NA

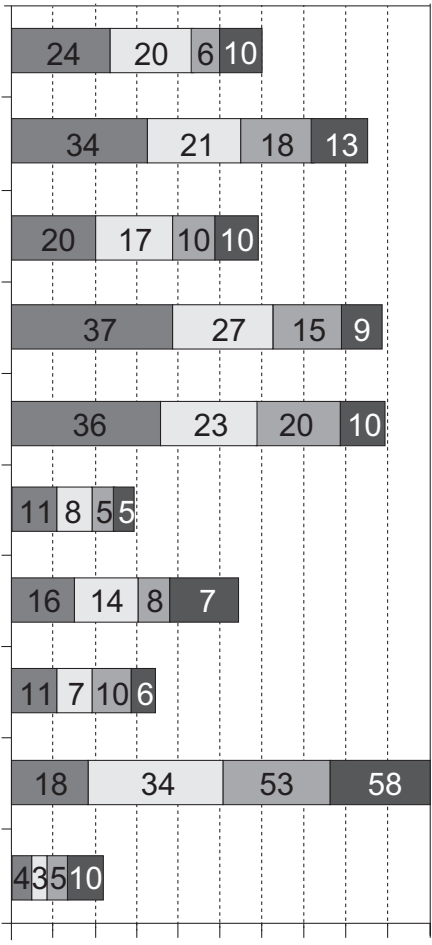

0102030405060708090100 [\%]

Interested and knowledgeable in MIL $\quad \square$ Uninterested but knowledgeable in MIL $\square$ Interested but unknowleggeable in MIL Uninterested and unknowledgeable in MIL

Figure 5. Which of the following MIL-related activities have you noticed in the past 12 months? (\%) $\mathrm{N}=1017$. 
The question 'Who do you think is responsible for media literacy skill acquisition?' related to media politics indirectly. It explains the respondent views on who should be responsible for the acquisition of MIL skills and knowledge. All groups agreed that MIL skills and knowledge are an individual's responsibility as well as the responsibility of the education system and governmental institutions. The individual's responsibility is emphasised the most by group 3 (94\%) and the least by group 4 (71\%; Figure 6). Group 1 placed more responsibility on mass media (37\%); and Group 2 believed local governments should provide courses on MIL (16\%). The interested respondents (Groups 1 and 2, respectively, 10\% and 9\%) claimed that MIL education should be provided in libraries, while Group 4 suggested that MIL education would fall upon media researchers (14\%).

\section{CONCLUSIONS AND DISCUSSION}

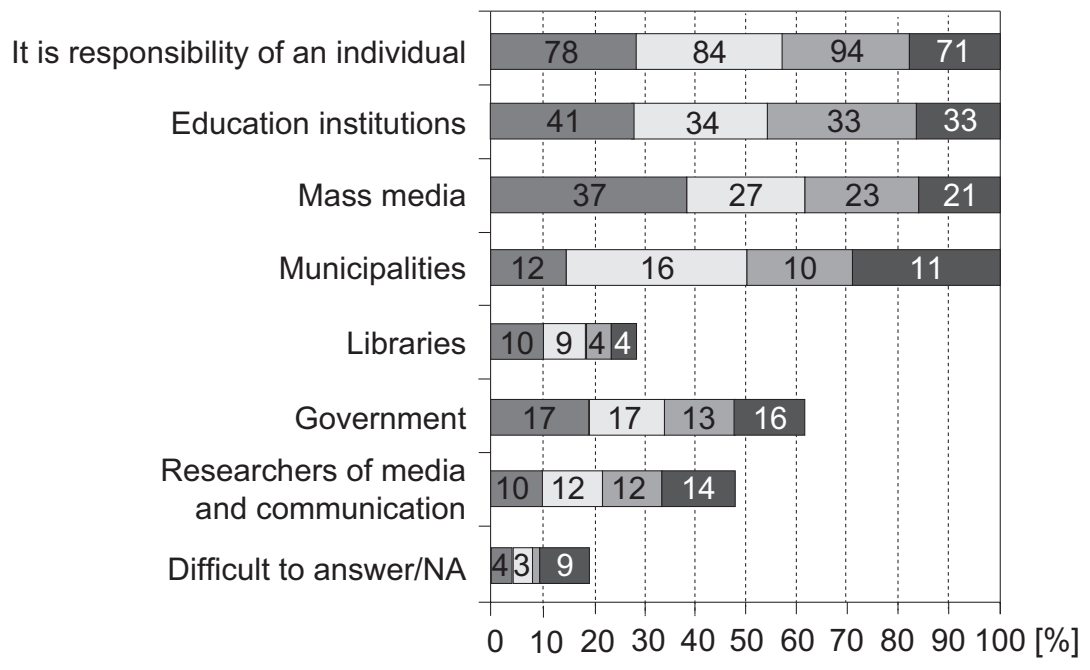

Interested and knowledgeable in MIL $\square$ Uninterested but knowledgeable in MIL

$\square$ Interested but unknowleggeable in MIL $\square$ Uninterested and unknowledgeable in MIL

Figure 6. Who do you think is responsible for media literacy skill acquisition? (\%) N=1017.

The study results indicate that respondents' interest and knowledge regarding MIL are mainly influenced by the level of their education and income. The educated and interested respondents noticed significantly more MIL activities than the other respondents. Respondents with a higher education level, females and people with higher income tended to take MIL-related threats more seriously. In the beginning of this article, we posed three research questions, and we will now go through the answers to those questions. 
RQ1 has been stated as: 'What characterises the society's perception of MIL in Latvia?' Although the generational gap is not a crucial factor when it comes to MIL, younger and better-educated people, regardless of interest level, tended to evaluate their own MIL knowledge more highly; the same applies to the risks arising from lack of knowledge. Middle-aged and elderly respondents (aged 55-63; 64-75) displayed less interest and lower self-evaluation of MIL skills and knowledge. The differences across generations could be linked to digital experience; younger people tend to look for information on the internet, thus noticing threats. The age-related differences in terms of threat and activity evaluation are not as great; these are displayed mainly amongst the youngest (18-24) and the oldest (64-75) groups.

Latvian society's information acquisition is characterised by two different languages — Latvian and Russian - and, therefore, each ethnic group uses different media and information sources (the Russian-speaking society mainly uses and trusts Russian media). However, survey data shows that MIL perception is not influenced by ethnicity or the language spoken in the family. A greater difference shows among citizens and non-citizens, which could, however, be more related to age than ethnicity, as the greater part of non-citizens are over 50 years old (Central Statistical Bureau, 2018).

RQ2 reads as follows: 'How do the level and quality of information about MIL among the general population in Latvia correlate with the importance given to MIL in the framework of competences needed to participate in social life, ensuring social welfare and safety?' Respondents with different interest and knowledge levels tended to evaluate MIL knowledge, or lack thereof, related to threats rather similarly. Most respondents linked insufficient MIL knowledge to threats to child safety or society's safety in general, as well as to a decrease in society's wellbeing, prosperity and education level. The identification of skills and knowledge necessary to prevent these threats was not related to interest and knowledge level. All group representatives emphasised the practical aspects of MIL: skills and knowledge that could be useful in daily use of media and in navigating the digital environment.

The study showed that respondents associated MIL knowledge, skills, and solutions to the impact of digitization on all aspects of daily life. Respondents claimed that it created threats which may not be overcome with the existing skills and knowledge. Youth, the educated and MIL-interested respondents identified a higher level of threat and showed more readiness to seek solutions to the consequences of insufficient MIL knowledge and skill.

Of the provided solutions for how to decrease insufficient MIL knowledge risks, the respondents tended to choose the solutions linked to regulations. The largest portion of survey participants chose answers related to encouraging transparency of media and global platform operations; respondents supported increased accountability via regulation and self-regulation and active fights against disinformation.

Furthermore, data showed that the speed and variety brought by developing technology, as well as the increasing dependency on media, caused a variety of concerns, mostly related to threats to their own security or the security of others, 
primarily children. Respondents agreed to threat-minimising solutions related to stricter rules and the setting of boundaries and limits in the environment which impact individuals and society both temporarily and long-term.

As RQ3, we asked: 'To what extent have the media policy measures for promoting MIL reached the Latvian population?' The Latvian media politics activity plan involves activities which have reached approximately one-half of the society, as $41 \%$ had not noticed MIL-promoting activities and $10 \%$ did not respond to the question. MIL activities were noticed by those with interest and knowledge about MIL.

The respondents have most frequently noticed media content related to MIL, which means that content provided by the Media Support Fund is likely to be noticed by society and reveals the efficiency of specific media politics actions. The respondents also noticed processes indirectly related to media actions: every fifth respondent claimed that society's interest about media activity was growing, mediarelated knowledge is improving, and more material and expert explanations on disinformation and technology use were available.

All respondent groups were aware of individual responsibility regarding media literacy. This coincides with Sonia Livingstone's claim that media politics nowadays has placed the MIL-related problems on the individual (EPALE, 2018), disregarding the fact that MIL is not a quickly achievable improvement, it is costly and will never reach the entire society (Livingstone, 2018).

The respondents focused on child and adolescent safety, which might be one of the reasons why risk minimising is linked to primary and secondary education: respondents believed that the curriculum must include MIL knowledge and skills. A major role in MIL improvement was attributed to the government, municipalities and tertiary education institutions. Respondents emphasised the necessity of including the whole society in MIL issues by providing lifelong education. The view that MIL should not only be addressed to children and adolescents contradicts current media politics, which has planned most activities for the younger society and those who work with youth. Respondents agreed that MIL education should mainly be addressed to teachers (58\%), pupils (52\%), students (39\%), journalists (30\%) and seniors (26\%).

The results of the MIL activist network survey, created by the Ministry of Culture, support these conclusions. They show that the understanding of MIL policies in society is to some extent relatable to the activities that have already been implemented, which are closely connected to the respective organizations' main fields of activity. Almost one-third of the activists that responded (9 out of 28 responses) represented universities and tertiary education institutions and came from the fields of education (13) and information and communication (12). Others included six NGO's, five state institutions and four libraries.

Most of the activities that these institutions provided involved education of young people. Twelve organisations were involved in the education of school level young people, the same number taught university students, and only nine of the participants in the activist network stated that they have life-long learning MIL 
projects. In terms of activity target audiences, one-half of all activists stated that they work with young people (17). Often the target groups were those who work with young audiences professionally — such as teachers (16) and librarians (14). A slightly smaller number of projects (13) were directed to work with primary school children, whereas pre-school children and seniors, as well as several other potential groups - entrepreneurs and managers, scientists and the unemployed were only targeted in one or two of the projects.

There are preferences also in the forms of activity used - it was found that most of the institutions that responded to the survey questions organised courses and seminars (19), conferences and discussions (18) and lectures (19). However, practical seminars are even more popular ( 23 of 29 organizations organized practical seminars). Fact-checking activities are also relatively popular (13).

New media has changed the media landscape, and the need for changes in the literacy concept were recognized by Latvian media and education policymakers, but it was widely understood and embraced as a need for digital and ITC only. In this context, the 2016 new media policy document (Cabinet of Ministers, 2016) introduced a concept of MIL in a new way. First, the policy was built upon the European tradition of strong public media and a self-regulation philosophy. Second, even if cyber-safety was an important issue, changes in global geopolitical situations pushed forward the primacy of the issues of disinformation, fake news and propaganda (and underlined the need for critical thinking and fact-checking skills). Third, the document addressed media, education (including universities) and public sector institutions as the main actors in the network of implementation of the policy; other actors like NGOs and entrepreneurs, etc. were welcomed but not clearly pointed out or supported. Ideologically, the agenda proposed by the policy is more understandable and appealing to those who are well-educated and wellsituated in the society, if not only calling for the attention of people that are in one way or another gathering around schools, universities, media and libraries - the state's main 'ideological apparatuses' (Althusser, 1970, 2006).

This explains how audiences in Latvia perceive MIL in general - from one side there is growing interest in MIL. In addition, people believe that there is a growth in MIL as well. However, the majority of the audience are still uninterested in MIL. People in Latvia have noticed and would like to receive MIL education via the media, but they are much less interested in mass media ethics or self-regulation issues or issues concerning journalistic quality. The main action in the field of MIL is expected from educational and research institutions and, obviously, not from other fields. This is because, in the view of the biggest part of respondents, media literacy like every literacy is considered as an outcome of education content and process, and the responsibility for those outcomes is put on the shoulders of a small number of professional educators and librarians. The respondents are lacking the clear understanding and analytic and constructive perspective on society in which contemporary multiple media is underlined in its importance, complexity 
and interactions with other actors of the public space. Consequently, little action is expected from the government, and the government's role in diminishing risks through enhanced media literacy is not appreciated. In other words, through all measures taken by the government and its social partners, society has not apprehended a systemic and integrated view on MIL and how the government should act in order to diminish risks and threats connected to the lack of MIL. Only some aspects of MIL are sized and no operationalization of the approach in a systemic way is possible. Our conclusion is that this problem is connected to the rather narrow definition of MIL included in the policy documents (Cabinet of Ministers, 2016). The definition shows that the policy has been more oriented on MIL as a reactive tool that supports a citizen to fight against outer dangers, leaving a broad range of issues connecting to the (pro)active citizenship that demands and takes part in the creation of healthy information space based on democratic values.

In this context, the most interesting aspect of the research results is the paradox that shows people are concerned with threats to their own and their property's safety, and with this concern they would like stronger rules and monitoring of media from the government side. At the same time, most of the respondents stated that the responsibility for achieving MIL must be taken on by individuals themselves flawed individuals who blame their education and are not ready for independent critical thinking and socially responsible action during their life after school. These results correspond clearly with the previous research on the Latvian people dealing with pluralism - safety in different contexts dominates as a value over more liberal values (Kruks, 2018). Our final conclusion is that, working for the future, Latvian media policy should address social values to understand gaps and consequences of the policy; first of all, democratic values such as press freedom, quality journalism and participation in order to integrate MIL into the everyday perspective of its citizens for better understanding of common interests.

\section{REFERENCES}

Althusser, L. ([1970]2006). Ideology and ideological state apparatuses (notes towards an investigation). In A. Sharma \& A. Gupta (Eds.), The anthropology of the state: A reader (pp. 86-98). Blackwell Publishing.

Andžāns, M., Bruğe, I. Daugulis, M., A. Rožukalne \& A., Sprūds, A. (2016). Latvijas plašsaziņas lìdzeklı noturība pret citu valstu vēstījumiem: Krievijas faktors NATO 2016. gada Varšavas samita kontekstā [Resilience of Latvian mass media to the narratives of the other countries: The Russia's factor in the context of NATO's 2016 Warsaw Summit]. Latvijas ārpolitikas institūts.

Buckingham, D. (2003). Media education: Literacy, learning and contemporary culture. Polity Press.

Buckingham, D. (2015). Do we really need media education 2.0? Teaching media in the age of participatory culture. In T.-B. Lin, D.T.V. Chen \& C.S. Chai (Eds.), New media and learning in the 21st century (pp. 9-21). Springer.

Cappello, G. (2017). Literacy, media literacy and social change: Where do we go from now? Italian Journal of Sociology of Education, 9(1), 31-44. https://doi.org/10.14658/pupj-ijse-2017-1-3.

Central Statistical Bureau. (2018, December 19). Lower birth and migration rates recorded in Latvia. 
https://www.csb.gov.lv/en/statistics/statistics-by-theme/population/number-and-change/searchin-theme/2444-number-population-latvia-2018.

Chu, D., \& Lee, A.Y.L. (2014). Media education initiatives by media organizations: The uses of media literacy in Hong Kong media. Journalism and Communication Educator, 69(2), 127-145. https:// doi.org/10.1177/1077695813517884.

Dimants, A. (2018). Latvia: Different journalistic cultures and different accountability within one media system. In T. Eberwein, S. Fengler \& M. Karmasin (Eds.), The European handbook of media accountability (pp.143-149). Routledge.

Dobek-Ostrowska, B. (2015). 25 years after communism: Four models of media and politics in Central and Eastern Europe. In B. Dobek-Ostrowska \& M. Glowacki (Eds.), Democracy and media in Central and Eastern Europe 25 years on (pp. 11-45). Peter Lang.

Elmborg, J. (2012). Critical information literacy: Definitions and challenges. In C.W. Wilkinson \& C. Bruch (Eds.), Transforming information literacy programs: Intersecting frontiers of self, library culture, and campus community (pp. 75-80). Association of College and Research Libraries.

EPALE (2018, November 8). Annual UNESCO media and information literacy conference in Kaunas, Lithuania. https://epale.ec.europa.eu/en/content/annual-unesco-media-and-information-literacyconference-kaunas-lithuania- 0 .

European Commission (2018). Communication from the Commission to The European Parliament, The Council, The European Economic and Social Committee and The Committee of The Regions: Tackling online disinformation: A European approach. https://eur-lex.europa.eu/legal-content/ EN/TXT/?uri=CELEX:52018DC0236.

European Parliament and the Council of the EU (2006). Recommendation of The European Parliament and $O f$ the Council of 20 December 2006 on the protection of minors and human dignity and on the right of reply in relation to the competitiveness of the European audiovisual and on-line information services industry. https://eur-lex.europa.eu/legal-content/EN/ALL/?uri=CELEX\%3A32006H0952

European Parliament and the Council of the EU (2018). Directive (EU) 2018/1808 of the European Parliament and of the Council. https://eur-lex.europa.eu/eli/dir/2018/1808/oj.

European Parliament (2017). European Parliament resolution of 14 September 2017 on a new skills agenda for Europe. http://www.europarl.europa.eu/doceo/document/TA-8-2017-0360_EN.html.

European Parliament (2018). European Parliament resolution of 3 May 2018 on media pluralism and media freedom in the European Union. http://www.europarl.europa.eu/doceo/document/TA-82018-0204_EN.pdf.

Frau-Meigs, D., \& Torrent, J. (2009). Mapping media education policies in the world: Visions, programs and challenges. United Nations Alliance of Civilizations and Grupo Communicare.

Frau-Meigs, D., Velez, I., \& Michel, J.F. (2017). Mapping media and information literacy policies: new perspectives for the governance of MIL. In D. Frau-Meigs, I. Velez \& J.F. Michel (Eds.), Public policies in media and information literacy in Europe: Cross-country comparisons (pp. 19-88). Taylor \& Francis.

Freibergs, V. (2016). Mapping media literacy in Latvia: National summary. In European Audiovisual Observatory. Mapping of media literacy practices and actions in EU-28 (pp. 274-284). European Audiovisual Observatory.

Freire, P. (1970). Pedagogy of the oppressed. Seabury Press.

Gee, J. P. (2015). The new literacy studies. In J. Rowsell \& K. Pahl (Eds.), The Routledge handbook of literacy studies. Routledge.

Gee, J. P. (1996). Social linguistics and literacies: Ideology in discourses (2nd ed). Falmer Press.

Hallin, G., \& Mancini, P. (2004). Comparing media systems: Three models of media and politics. Cambridge University Press.

Hobbs, R. (1998). The seven great debates in the media literacy movement. Journal of Communication, 48(1), 16-31. https://doi.org/10.1111/j.1460-2466.1998.tb02734.x.

Ivāne, I. (2015). Digitālā kompetence izglìtības procesā [Digital competence in education process]. Izglìtibas un zinātnes ministrija. https://izm.gov.lv/images/sabiedriska_lidzdaliba/aktualitates/ NEPLP_110515_ppt.pdf. 
Jastramskis, D., Rožukalne, A., \& Jõesaar, A. (2017). Media concentration in the Baltic States, 20002014. Informacijos mokslai, 77, 26-48. https://doi.org/10.15388/Im.2017.77.10705.

Koltay, T. (2011). The media and the literacies: Media literacy, information literacy, digital literacy. Media, Culture \& Society, 33(2), 211-221. https://doi.org/10.1177/0163443710393382.

Kaktiņš, A. (May 19, 2017). Cik uzṇēmīgi pret viltus ziņām ir Latvijas iedzīvotāji? [How susceptible to false news are inhabitants of Latvia?] Paper presented at conference Security of Latvia in $21^{\text {st }}$ century. Fake news - smoldering growing threat. Presidential Chancery.

Kennel, T. (2008). Area frame. In P. Lavrakas, P. (Ed.), Encyclopedia of Survey Research Methods (pp. 32-33). Sage.

Kress, G. (2003). Literacy in the new media age. Routledge.

Kruks. S. (2018). Enabling agency among Latvians: Cultural socialization and political procedures. In S. Kruks (Ed.) Pluralism anxiety: Acting socially in Latvia (pp. 14-41). Riga Stradiņ̌̌ University.

Centre of Culture Information Systems (n.d.). Publisko bibliotēku attīstības projekts "Trešais tēva dēls" [Public library development project "Father's third son"]. http://www.kis.gov.lv/projekti/bibliotekam/publisko-biblioteku-attistibas-projekts/.

Laizāne, M., Putniṇa, A., \& Mileiko, I. (2015). Mazākumtautību skolu skolēnu identitāte un piederība Latvijai [Identity and affiliation of ethnic minority school pupils to Latvia]. https://www.ascendum. lv/notikumi/petijuma-par-mazakumtautibu-skolu-skolenu-piederibas-sajutu-latvijai-rezultati.html

Latvia's facts (2017). Latvijas iedzìvotāju medijpratība [Media literacy of Latvian population]. https:// www.km.gov.lv/uploads/ckeditor/files/mediju_politika/petijumi/Medijpratiba_petijuma\%20rezultati_Latvijas\%20Fakti_18_07_2017.pdf.

University of Latvia (n.d.). Topošăs skolotāju programmas [Future teachers' programs]. https://www. lu.lv/studijas/fakultates/pedagogijas-psihologijas-un-makslas-fakultate/bakalaura-limenastudijas/toposas-skolotaju-programmas/.

Leaning, M. (2017). Media and information literacy: An integrated approach. Chandos Publishing.

Livingstone, S. (2004). Media literacy and the challenge of new information and communication technologies. The Communication Review, 7(1), 3-14. https://doi.org/10.1080/10714420490280152

Livingstone, S. (2014). Developing social media literacy: how children learn to interpret risky opportunities on social network sites. Communications, 39(3), 283-303. https://doi.org/10.1515/ commun-2014-0113.

Livingstone, S. (2018, May 8). Media literacy - everyone's favourite solution to the problems of regulation. https://blogs.lse.ac.uk/medialse/2018/05/08/media-literacy-everyones-favourite-solutionto-the-problems-of-regulation/.

Loveless, A., \& Longman, D. (1998). Information literacy: Innuendo or insight? Education and Information Technologies, 3(1), 27-40. https://doi.org/10.1023/A:1009646204674.

LR Ministry of Culture (n.d.). Mediju politika [Media politics]. https://www.km.gov.lv/lv/medijupolitika/atbildes-uz-biezak-uzdotajiem-jautajumiem.

LR Parliament (2018). Krievijas ietekme Latvijas informatìvajā telpā [Russia's influence in information environment of Latvia]. https://www.saeima.lv/petijumi/Krievijas_ietekme_Latvijas_informativaja_telpa_elektroniski.pdf.

Luke, A. (2012). Critical literacy: Foundational notes. Theory into Practice, 51(1), 4-11. https://doi.or $\mathrm{g} / 10.1080 / 00405841.2012 .636324$.

Cabinet of Ministers (2016). Latvijas mediju politikas pamatnostādnes 2016.-2020. gadam [Guidelines of Latvia's media politics 2016-2020]. https://likumi.lv/ta/id/286455-par-latvijas-medijupolitikas-pamatnostadnem-2016-2020-gadam.

Ministry of Foreign Affairs (2018). Citizenship policy in Latvia. https://www.mfa.gov.lv/en/policy/ society-integration/citizenship/citizenship-policy-in-latvia.

MPM (2015). Media pluralism monitor: Latvia. https://cmpf.eui.eu/mpm-2015/latvia/.

MPM (2016). Media pluralism monitor: Results, Latvia. https://cmpf.eui.eu/media-pluralism-monitor/mpm-2016-results/latvia/.

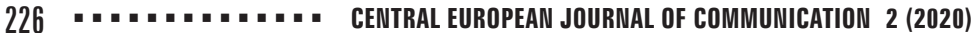

Central European Journal of Communication Volume 13, No 2 (26), Special Issue 2020

(C) for this edition by CNS 
MPM (2018). Media pluralism monitor 2017: Country results, Latvia. https://cadmus.eui.eu/bitstream/ handle/1814/61146/2018_Latvia_EN.pdf?sequence=18isAllowed=y.

Cross-Sectoral Coordination Centre (2012). Latvijas nacionālais attīstības plāns 2014.-2020. gadam [National Development Plan of Latvia 2014-2020]. http://polsis.mk.gov.lv/documents/4247.

Cross-Sectoral Coordination Centre (2019). Latvijas nacionālais attīstības plāns 2021.-2027. gadam. [National development plan of Latvia 2021-2027.] https://www.pkc.gov.lv/sites/default/ files/2019-10/20190927_NAP_2021_2027_1_redakcija_publiskajai_apspriesanai_FINAL.pdf.

Rožukalne, A., \& Sedlenieks, K. (2017). The elusive cyber beasts: How to identify the communication of pro-Russian hybrid trolls in Latvia's internet news sites? Central European Journal of Communication, 10(1)18, 79-97. https://doi.org/10.19195/1899-5101.10.1(18).6.

Skola 2030 (n.d.) Mācību priekšmetu programmas pamatizglìtībā [School 2030: Subject programs in primary education]. http://www.skola2030.lv/lv.

Skudra, O., Šulmane, I. \& Dreijere, V. (2014). Plašsazinas līdzekḷi demokrātiskā sabiedrībā [Mass media in democratic society]. In J. Rozenvalds (Ed.) Cik demokrātiska ir Latvija? Demokrātijas audits, 2005-2014 [How democratic Latvia is? Democracy audit, 2005-2014] (pp.193-208). LU Sociālo un politisko pētījumu institūts.

Song, A. (2017). Critical media literacies in the twenty-first century: Writing autoethnographies, making connections, and creating virtual identities. Journal of Media Literacy Education, 9(1), 64-78.

Spurava, G. (2017). Pètījums par 9 lìdz 16 gadus vecu bērnu un pusaudžu medijpratību latvijā [Research on media literacy of children aged from 9 to 16 in Latvia]. https://www.km.gov.lv/uploads/ckeditor/files/mediju_politika/medijprat\%C4\%ABba/petijums/2018/Bernu\%20un\%20pusaudzu\%20medijpratibas\%20petijuma\%20rezultati.pdf.

Stakle, A. (2011). Mediju kompetence ilgtspējīgā skolotāju izglìtībā. Promocijas darbs. [Media literacy in sustainable teacher education. Doctoral dissertation.] Daugavpils University.

Standard Eurobarometer 90 (2018). Media use in European Union. Autumn 2018. https://ec.europa. $\mathrm{eu} / \mathrm{commfrontoffice/publicopinion/index.cfm/ResultDoc/downl} \mathrm{oad/DocumentKy/86433.}$

Street, B. (1994). Cross-cultural perspectives on literacy. In L.T. Verhoeven (Ed.), Functional literacy: Theoretical issues and educational implications (pp. 95-111). John Benjamins Publishing Company.

Street, B. (1997). The implications of the "new literacy studies" for literacy education. English in Education, 31(3), 45-59. https://doi.org/10.1111/j.1754-8845.1997.tb00133.x.

Street, B. (2003). What's 'new' in new literacy studies? Critical approaches to literacy in theory and practice. Current issues in comparative education, 5(2), 77-91.

Street, B. (2006). Autonomous and ideological models of literacy: Approaches from new literacy studies. http://www.media-anthropology.net/street_newliteracy.pdf.

Street, B.V. (1984). Literacy in theory and practice. Cambridge University Press.

Street, B.V. (2005). At last: Recent applications of new literacy studies in educational contexts. Research in the Teaching of English, 39(4), 417-423.

Street, B.V. (2011). Literacy inequalities in theory and practice: The power to name and define. International Journal of Educational Development, 31(6), 580-586. https://doi.org/10.1016/j. ijedudev.2010.09.005.

Trültzsch-Wijnen, C.W., Murru, M.F., \& Papaioannou, T. (2017). Definitions and values of media and information literacy in a historical context. In D. Frau-Meigs, I. Velez \& J.F. Michel (Eds.), Public policies in media and information literacy in Europe: Cross-country comparisons (pp. 95-115). Taylor \& Francis.

UNESCO (2013). Global media and information literacy assessment framework: Country readiness and competencies. https://unesdoc.unesco.org/ark:/48223/pf0000224655. 


\section{APPENDIX A}

\section{TECHNICAL INFORMATION ON THE SURVEY}

Conductor of research

General population

18 to 75

Planned research sample

Attained research sample

Sampling method

Indicators of stratification

Survey method

Geographical scope

Dates of survey
Research centre SKDS

Permanent residents of Latvia aged

1000 respondents (representative of the general

population

1017 respondents

Stratified random sampling

Administrative territorial

Direct interviews at respondents' residences

All regions of Latvia (127 sampling points)

From 11.05.2019 until 22.05.2019

\section{COMPARISON OF THE ATTAINED SAMPLE WITH THE POPULATION STATISTICS}

\begin{tabular}{|l|c|c|c|}
\hline & $\begin{array}{c}\text { No of respondents } \\
\text { in the sample (\%) } \\
\text { before weighting }\end{array}$ & $\begin{array}{c}\text { No of respondents in } \\
\text { the sample (\%) after } \\
\text { weighting }\end{array}$ & $\begin{array}{c}\text { Data of OCMA } \\
\text { Population Register }\end{array}$ \\
\hline TOTAL & $\mathbf{1 0 0 . 0}$ & $\mathbf{1 0 0 . 0}$ & $\mathbf{1 0 0 . 0}$ \\
\hline REGION & 33.2 & 33.4 & 33.4 \\
\hline Riga & 18.4 & 18.7 & 18.7 \\
\hline Pierīga & $8 . .8$ & 9.6 & 12.5 \\
\hline Vidzeme & 13.4 & 12.5 & 11.8 \\
\hline Kurzeme & 11.5 & 11.8 & 13.9 \\
\hline Zemgale & 14.7 & 13.9 & \\
\hline Latgale & & & 48.1 \\
\hline GENDER & 46.7 & 48.1 & 51.9 \\
\hline Male & 53.3 & 51.9 & \\
\hline Female & & & \\
\hline
\end{tabular}


Media education in the common interest

\begin{tabular}{|c|c|c|c|}
\hline \multicolumn{4}{|l|}{ ETHNICITY } \\
\hline Latvian & 60.2 & 58.9 & 58.9 \\
\hline Other & 39.8 & 41.1 & 41.1 \\
\hline \multicolumn{4}{|l|}{ AGE } \\
\hline $18-24$ y.o. & 10.2 & 8.6 & 8.6 \\
\hline $25-34$ y.o. & 19.8 & 20.1 & 20.1 \\
\hline 35-44 y.o. & 20.5 & 19.1 & 19.1 \\
\hline 45-54 y.o. & 16.6 & 18.9 & 18.9 \\
\hline 55-63 у.о. & 15.9 & 17.3 & 17.3 \\
\hline $64-75$ у.о. & 17.0 & 16.0 & 16.0 \\
\hline \multicolumn{4}{|l|}{ STATUS } \\
\hline Employed & 66.4 & 67.7 & \\
\hline Unemployed & 33.6 & 32.3 & \\
\hline \multicolumn{4}{|l|}{ EDUCATION } \\
\hline Basic education & 9.4 & 9.1 & \\
\hline $\begin{array}{l}\text { Secondary, } \\
\text { secondary } \\
\text { vocational }\end{array}$ & 63.1 & 63.3 & \\
\hline Higher & 27.4 & 27.6 & \\
\hline \multicolumn{4}{|l|}{ CITIZENSHIP } \\
\hline $\begin{array}{l}\text { Citizens of the } \\
\text { Republic of Latvia }\end{array}$ & 88.9 & 88.5 & \\
\hline $\begin{array}{l}\text { Residents without } \\
\text { citizenship of the } \\
\text { Republic of Latvia }\end{array}$ & 11.1 & 11.5 & \\
\hline
\end{tabular}

Source: Research centre SKDS. 